\title{
Resigning protein concentrates in dairy cattle nutrition: a problem or a chance?
}

\author{
FLORIAN LEIBER ${ }^{1}$
}

Key words: dairy cattle, feeding concepts, protein, concentrates, rumen fermentation

\begin{abstract}
Based on the assumption that the reduction of the use of imported protein concentrates, such as soybean from overseas, is a goal of ecologically sustainable livestock production, this paper is discussing significant aspects of dairy cows' demand for dietary protein. These aspects are put in a general context of rumen fermentation efficiency. The main question is, whether new perspectives on optimal rumen functioning could be found, which allow to develop low-input feed evaluation systems for dairy cattle, especially in organic farming. Besides the reduction in concentrated feedstuff these systems should enable to avoid nutrition based metabolic disorders of the cattle and to indicate advantageous side-effects coming along with lowconcentrate feeding. An approximate outline of research and development topics to achieve such systems is presented with this paper.
\end{abstract}

\section{Introduction}

Global needs for soybean as livestock feed are constantly increasing and are considered as a serious environmental and social problem (von Witzke et al., 2011). Generally, but in particular related to soybean, the global land requirements for animal products increase and are prospected to go far beyond the ecological capacity of the earth within the few next decades (Pelletier \& Tyedmers, 2010). Especially animal production in European countries relies to a very large degree on soybean imports as the main vegetable protein source for almost all livestock species. Whereas for monogastric species the possibility to resign dietary concentrates is limited, the nutritional physiology of ruminants might allow for considerable reductions in this field. Due to their digestion physiology, which combines fermentation, chewing and particle sorting in a unique way, ruminants, in particular cattle, are able to degrade plant fibres very efficiently (Clauss et al., 2010) and to gain metabolizable energy from roughages which are poor in soluble carbohydrates like sugars or starch. This is the big advantage of ruminants compared to monogastric animals. Correspondingly, ruminants developed a metabolic pathway to reuse blood urea as a nitrogen source by secreting it into the rumen instead of renal excretion and are thus also able to use dietary nitrogen very efficiently (Van Soest, 1994), especially when the supply is low. Based on these considerations, Organic Agriculture should have aim at reducing the use of protein concentrates (soybean) in livestock ruminants' feed rations. Given that goal, it appears necessary to reassess the need of dairy cows for dietary protein in high-roughage feeding systems and to indicate the potential and constraints for resigning or at least reducing dietary protein concentrates.

\section{Protein demands in dairy cow nutrition}

The demand of dairy cattle for dietary protein is mostly defined in the national feeding recommendations for livestock. It is usually separated into requirements for maintenance and for milk production and for example based on usability (German system; GfE, 2001) or absorbability (Swiss system; Agroscope, 2013) at the abomasum and duodenum. By this, the ruminal conversion of feed into microbial protein is taken into account, usually based on models which thoroughly consider the contribution of the different feed components to microbial fermentation and degradability of the diet. Thus, the "ruminal" protein demand is defined in quite dynamic and complex models. The endogenous part of the protein demand is not described in such a dynamic way but more or less fixed per $\mathrm{kg}$ of body weight and $\mathrm{kg}$ of milk yield. These systems allow calculating accurately the dietary demands for given milk yields or - vice versa - the milk production potential of a given diet.

In practice, the farm extension programmes tend to recommend rather too high than too low protein balances in order to be safe in maintaining high milk yields. One indicator for appropriate protein supply of a dairy cow is the urea concentration in the milk, where minimal thresholds are defined, beyond which a cow is expected to develop metabolic disorders.

\footnotetext{
${ }^{1}$ Research Institute of Organic Agriculture FiBL,Switzerland, Departement of Livestock Sciences, www.fibl.org; florian.leiber@fibl.org.
} 
However, recent experiences in concentrate-free dairy herds in Switzerland show that cows being fed below their theoretical demands in dietary protein may have clearly higher milk yields than calculated, but at the same time less veterinary cases than comparable cows which receive protein concentrates according to the system demands (Furger et al., 2013). These cows show very low milk urea concentrations, which should indicate deficiency in protein supply. It can be assumed that under the specific conditions of the cited research work, the cows reused a large share of their blood urea via the rumino-hepatic circle (Van Soest, 1994). This implies an efficient use of nitrogen, meaning lower dietary demands and lower excretion via urine into the environment, and at the same time higher partitioning of feed protein into milk (Kälber et al., 2012). Further, the rumino-hepatic cycle leads to a lower metabolic pressure for detoxification of rumen-derived ammonia, which would improve the health status of the cows.

It appears that under optimal conditions in concentrate-free feeding systems a low dietary protein supply is not a problem but rather an advantage for the cow's metabolism and the environment. These optimal conditions, however, have to be determined. Forage quality on the one hand and rumen physiology on the other hand are of course the main factors, as in the conventional feeding systems. One key to gain a new position in dairy cows' feeding could be the question whether a maximal rumen fermentation rate is really the right goal in nutrition or not.

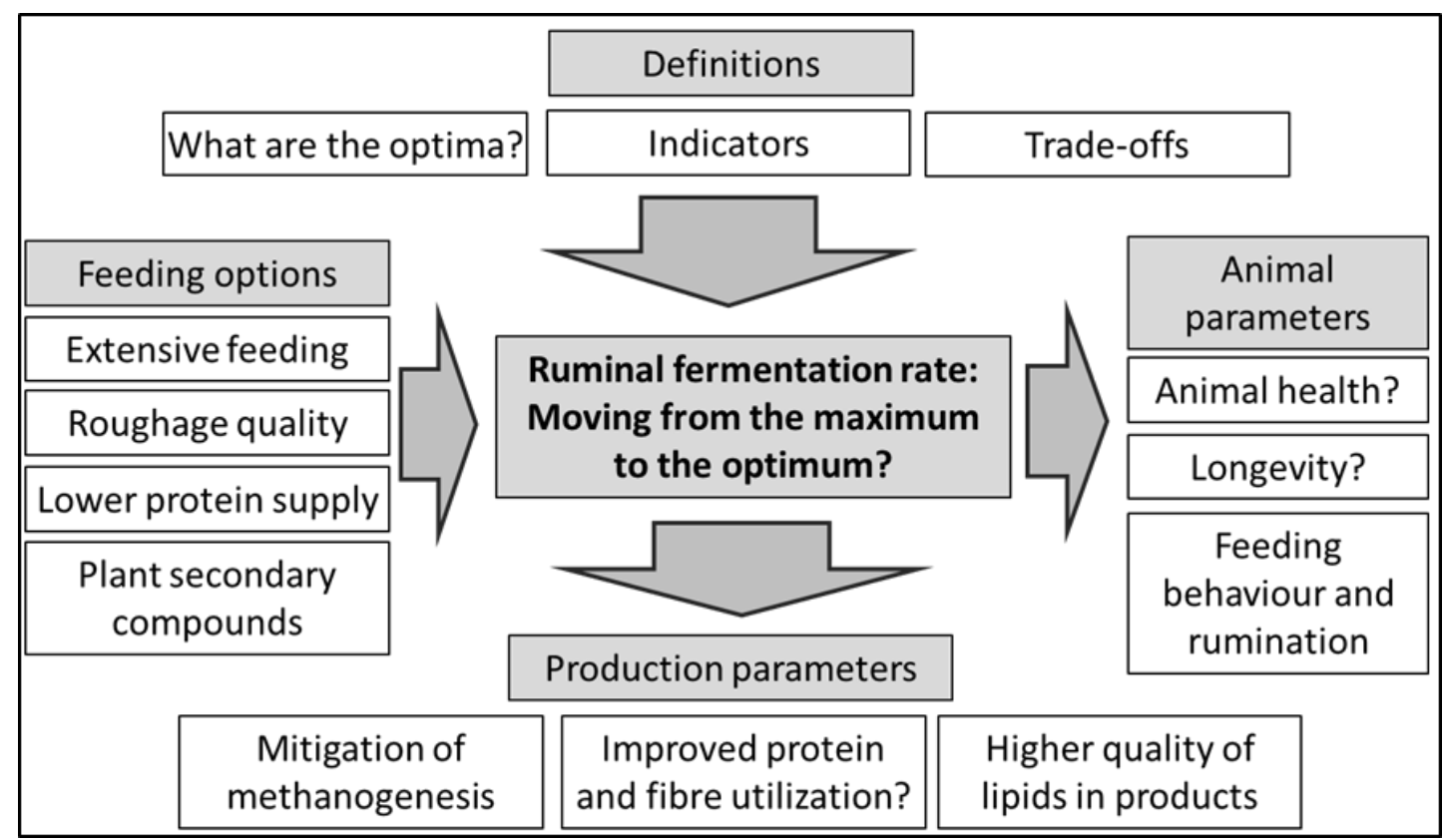

Figure 1. Possible framework of a research \& development agenda for optimized low-concentrate feeding systems for dairy cows

\section{The rumen fermentation: is the maximum the optimum?}

Contemporary feeding systems for dairy cows are usually aimed to achieve the maximum efficiency of rumen fermentation and at the same time the maximum of proteins (amino acids) reaching the duodenum for absorption. However, there are a number of issues which might serve to question whether the maximal rumen function is really the optimum for the ruminant itself, for the product quality, for the environment, and thus finally for the production system:

(i) If the rumen fermentation and microbial modification of nutrients would be $100 \%$ efficient, all polyunsaturated fatty acids, which are essential for any mammal, would be lost in this process and the ruminant could not survive. Therefore, mechanisms exist to interrupt the fermentation process: rumination has not only the function of physical fibre degradation, but it also brings the material from the rumen in contact with oxygen in the cow's mouth during chewing. This inhibits the attached rumen bacteria which are strictly anaerobe and thus stops the fermentation process. The chewing process further activates plant enzymes like the polyphenol oxidase (PPO) because of the contact with oxygen. The PPO is described to inhibit bacterial activity in the rumen thus protecting essential polyunsaturated fatty acids from being 
degraded by rumen bacteria (Buccioni et al., 2012). The same is supported by the ingestion of phenol rich plants, which therefore play an important role in ruminant diets (Jayanegara et al., 2011). Briefly summarized: partial inhibition of ruminal fermentation is part of the ruminants eating and digestion behaviour and saves essential plant substances for the endogenous metabolism.

(ii) The protection of polyunsaturated fatty acids in the rumen is essential for the ruminant itself, but it also enhances the quality of milk and meat, which may contain higher concentrations of omega- 3 fatty acids if the animals are fed with forages rich in PPO or phenolic compounds.

(iii) Also the mitigation of ruminal methane production can be achieved by the same phenolic substances in the diet, which however also implies a partial inhibition of rumen efficiency (Jayanegara et al., 2013).

These examples should introduce a perspective, in which not a maximal but a reduced rumen fermentation would be the goal to achieve an optimum in animal health, product quality, and environmental impact. Also a "low" dietary protein supply, which might reduce maximal microbial growth in the rumen, could be justified and reasonable in this context. However, it is necessary to note, that this is only one perspective, and many other aspects like the degree of fibre utilization and the metabolic animal health have to be kept in mind to achieve a sustainable system. Defining optimal rather than maximal rumen function as a goal in organic livestock systems would require many research activities under controlled as well as under practice conditions in order to find the real optima and the management options to achieve them. The target could be to develop own - organic and science based - feeding recommendations for dairy cows. Figure 1 displays important aspects for the development of such an organic or low-input feeding recommendation system.

\section{Conclusion}

On the background of the global challenge concerning the reduction of protein concentrates for livestock and of the indicated ability of dairy cattle to cope with lower protein supplies than recommended, it appears to be necessary to reassess the dietary protein needs of dairy cows fed on high-roughage diets. Further, it seems promising to investigate the specific conditions under which dairy cows can cope with low dietary protein supplies. This should be done in the context of a general investigation about the optimal rates of rumen function, which might be below the maximum, if animal health, environmental impacts and product quality are considered. In this sense, the resigning of protein concentrates from dairy cows' diets in organic farming could be a chance to reconsider the feeding paradigms for ruminant production in a broad perspective.

\section{References}

Agroscope, 2013. Fütterungsempfehlungen und Nährwerttabellen für Wiederkäuer. http://www.agroscope.admin.ch/futtermitteldatenbank/04834/index.html Accessed September 18, 2013.

Buccioni, A., Decandia, M., Minieri, S., Molle, G., Cabiddu, A. 2012. Lipid metabolism in the rumen: New insights on lipolysis and biohydrogenation with an emphasis on the role of endogenous plant factors. Animal Feed Science and Technology 174:1-25.

Clauss, M., Hume, I.D. and Hummel, J. 2010. Evolutionary adaptations of ruminants and their potential relevance for modern production systems. Animal 4:979-992.

Furger, M., Kunz, P., Schaffner, M., Schwarzenberger, M., Bürgisser, M., Peer, G., Brandenburger, C. 2013. Hochleistungskühe füttern: mit oder ohne Kraftfutter? ETH-Schriftenreihe zur Tierernährung 36:11-25.

GfE (Gesellschaft für Ernährungsphysiologie - Ausschuss für Bedarfsnormen). 2001. Empfehlungen zur Energie- und Nährstoffversorgung der Milchkühe und Aufzuchtrinder. DLG, Frankfurt am Main, Germany.

Jayanegara, A., Kreuzer, M., Wina, E., Leiber, F. 2011. Significance of phenolic compounds in tropical forages for the ruminal bypass of polyunsaturated fatty acids and the appearance of biohydrogenation intermediates as examined in vitro. Animal Production Science 51:1127-1136.

Jayanegara, A., Marquardt, S., Wina, E., Kreuzer, M., Leiber, F. 2013. In vitro indictaions for favourable non-additive effects on ruminal methane mitigation between high-phenolic and high-quality forages. British Journal of Nutrition 109:615-622.

Kälber T., Kreuzer, M., Leiber, F. 2012. Silages containing buckwheat and chicory: quality, digestibility and nitrogen utilisation by lactating cows. Archives of Animal Nutrition 66:50-65.

Pelletier, N., Tyedmers, P. 2010. Forecasting potential global environmental costs of livestock production 2000-2050. PNAS 107: 18371-18374.

Van Soest, P.J. 1994. Nutritional ecology of the ruminant. Cornell University press, Ithaca.

Von Witzke, H., Noleppa, S., Zhirkova, I. 2011. Fleisch frisst Land. WWF-Studie, WWF Germany, Berlin.. 
LEIBER F

Resigning protein concentrates in dairy cattle nutrition: a problem or a chance? 